University of Nebraska - Lincoln

DigitalCommons@University of Nebraska - Lincoln

Publications from USDA-ARS / UNL Faculty

U.S. Department of Agriculture: Agricultural

Research Service, Lincoln, Nebraska

2009

Plant species composition and biofuel yields of conservation grasslands

Paul R. Adler

USDA-ARS, paul.adler@ars.usda.gov

Matt A. Sanderson

USDA-ARS

Paul J. Weimer

USDA-ARS

Kenneth P. Vogel

USDA-ARS, kvogel1@unl.edu

Follow this and additional works at: https://digitalcommons.unl.edu/usdaarsfacpub

Adler, Paul R.; Sanderson, Matt A.; Weimer, Paul J.; and Vogel, Kenneth P., "Plant species composition and biofuel yields of conservation grasslands" (2009). Publications from USDA-ARS / UNL Faculty. 1554. https://digitalcommons.unl.edu/usdaarsfacpub/1554

This Article is brought to you for free and open access by the U.S. Department of Agriculture: Agricultural Research Service, Lincoln, Nebraska at DigitalCommons@University of Nebraska - Lincoln. It has been accepted for inclusion in Publications from USDA-ARS / UNL Faculty by an authorized administrator of DigitalCommons@University of Nebraska - Lincoln. 


\title{
Plant species composition and biofuel yields of conservation grasslands
}

\author{
Paul R. Adler,${ }^{1,4}$ Matt A. Sanderson, ${ }^{1}$ Paul J. Weimer, ${ }^{2}$ and Kenneth P. Vogel ${ }^{3}$ \\ ${ }^{1}$ United States Department of Agriculture, Agricultural Research Service (USDA-ARS), Pasture Systems \\ and Watershed Management Research Unit, University Park, Pennsylvania 16802 USA \\ ${ }^{2}$ USD A-ARS, U.S. Dairy Forage Research Center, Madison, Wisconsin 53706 USA \\ ${ }^{3}$ USDA-ARS, Grain, Forage and Bioenergy Research Unit, University of Nebraska, Lincoln, Nebraska 68583 USA
}

\begin{abstract}
Marginal croplands, such as those in the Conservation Reserve Program (CRP), have been suggested as a source of biomass for biofuel production. However, little is known about the composition of plant species on these conservation grasslands or their potential for ethanol production. Our objective was to assess the potential of CRP and other conservation grasslands for biofuel production, describing the relationships of plant species richness and tall native $\mathrm{C}_{4}$ prairie grass abundance with plant chemical composition and the resulting potential ethanol yield. We determined plant species composition and diversity at multiple scales with the modified Whittaker plot technique, aboveground biomass, plant chemical composition, and potential ethanol yield at 34 sites across the major ecological regions of the northeastern USA. Conservation grasslands with higher numbers of plant species had lower biomass yields and a lower ethanol yield per unit biomass compared with sites with fewer species. Thus, biofuel yield per unit land area decreased by $77 \%$ as plant species richness increased from 3 to 12.8 species per $\mathrm{m}^{2}$. We found that, as tall native $\mathrm{C}_{4}$ prairie grass abundance increased from $1.7 \%$ to $81.6 \%$, the number of plant species decreased and aboveground biomass per unit land area and ethanol yield per unit biomass increased resulting in a $500 \%$ increased biofuel yield per unit land area. Plant species richness and composition are key determinants of biomass and ethanol yields from conservation grasslands and have implications for low-input high-diversity systems. Designing systems to include a large proportion of species with undesirable fermentation characteristics could reduce ethanol yields.
\end{abstract}

Key words: biodiversity; biofuel; $C_{4}$ grass; conservation reserve program; CRP; ethanol; grasslands; plant diversity; species richness; switchgrass; warm-season grass.

\section{INTRODUCTION}

Conservation grasslands serve to reduce soil erosion (Zheng et al. 2004), sequester carbon in the soil (Baer et al. 2002, McLauchlan et al. 2006), improve water quality (Lant et al. 2005), and enhance the wildlife habitat value of the landscape (Murray et al. 2003, Veech 2006). Land set aside for conservation purposes, such as in the Conservation Reserve Program (CRP), has been suggested as a readily available biomass feedstock resource in the United States (National Research Council 2000, De La Torre Ugarte et al. 2003). About 6.8 million of the 12.1 million ha of CRP land (1998 data) may be available for biomass feedstock production (De La Torre Ugarte et al. 2003). Developing alternative and complementary uses for CRP land, such as biofuel production, would provide an economic incentive to keep this land in perennial grass cover and maintain the environmental benefits of the CRP program.

Manuscript received 20 December 2007; revised 5 August 2008; accepted 20 November 2008; final version received 17 March 2009. Corresponding Editor: I. C. Burke.

${ }^{4}$ E-mail: paul.adler@ars.usda.gov
Little is known about the plant species composition or richness, abundance of native vs. nonnative species, aboveground biomass production, or potential biofuel yields on CRP and other conservation grasslands (Baer et al. 2002). Plant community composition and biomass productivity are influenced by many factors including site productivity (Michalet et al. 2006), soil nutrient status (Gough et al. 2000), history of community assembly (Fukami and Morin 2003), latitude (Partel et al. 2007), and management history (Collins et al. 1998). Plant diversity has been suggested as a way to maximize sustainable biomass production of prairies on degraded lands for biofuel production (Tilman et al. 2006).

Ethanol yields vary with plant species resulting from differences in plant cell wall structural chemistry affecting both the carbohydrate composition and efficiency of enzymatic hydrolysis (Dien et al. 2006). Although there is little information on how different plant species affect ethanol yield (Dien et al. 2006), there are ample data demonstrating that plant composition affects forage quality for animals (Fales and Fritz 2007), but limited information is available on the effect of plant diversity (Tracy and Faulkner 2006). Our objective was 
to assess the potential of CRP and other conservation grasslands for biofuel production, describing the relationships of plant species richness and tall native $\mathrm{C}_{4}$ prairie grass abundance with plant chemical composition and the resulting potential ethanol yield.

\section{Methods}

The majority of CRP (Conservation Reserve Program) and CREP (Conservation Reserve Enhancement Program) lands are planted in cool-season $\left(\mathrm{C}_{3}\right)$ grasses in the northeastern United States. We focused our study on warm-season $\left(\mathrm{C}_{4}\right)$ grass sites because $\mathrm{C}_{4}$ grasses have been emphasized as biomass crops (Sanderson et al. 2004). We included CRP, CREP, WHIP (Wildlife Habitat Incentives Program), Partners for Wildlife, National Wildlife Refuges, State Parks, Wildlife Management Areas, Pennsylvania State Game Lands, mine land reclamation sites, and other grasslands in the northeast region of the United States. Most sites had a previous land use history of either row crops or hay/pasture. We worked with resource management professionals in several state and federal agencies to identify and obtain permissions to sample individual sites. We chose 34 warm-season grassland sites in New York, Pennsylvania, New Jersey, Maryland, and Virginia and sampled them during late August through mid October in 2002 and 2003 when plants were fully mature (late seed set or beyond) but before first frost. Six sites were sampled both years. Sampling locations covered the major ecological regions of the northeastern United States (Fig. 1; Bailey 1995).

We used the modified Whittaker plot (Stohlgren et al. 1995 , 1998) to quantify plant species richness and composition within each conservation grassland. Species richness was recorded at four scales $(1,10,100$, and 1000 $\left.\mathrm{m}^{2}\right)$ with this method. The outer $1000-\mathrm{m}^{2}$ plot $(50 \times 20$ $\mathrm{m})$ contains one $100-\mathrm{m}^{2}$ plot, two $10-\mathrm{m}^{2}$ plots, and $101-$ $\mathrm{m}^{2}$ plots. We compiled complete lists of the species present in all plots at all scales and visually estimated plant species cover in each of the $101-\mathrm{m}^{2}$ plots. Plant species nomenclature, functional group, and U.S. nativity were as defined on the National PLANTS Database (available online). ${ }^{5}$ Aboveground biomass and soil samples, management history, initial species seeded, and landscape details were obtained from each location along with weather data. Ten $1-\mathrm{m}^{2}$ plots, at the four corners and adjacent to the six $1-\mathrm{m}^{2}$ plots, surrounding the outside of each Whittaker plot were harvested to determine the amount of standing biomass. The plots were harvested at a $10-\mathrm{cm}$ stubble height and the biomass was dried at $55^{\circ} \mathrm{C}$. The dried biomass samples were ground first in a hammer mill and then ground to pass a 1-mm screen of a Wiley mill (Thomas Scientific, Swedesboro, New Jersey, USA).

\footnotetext{
${ }^{5}\langle$ http://plants.usda.gov $\rangle$
}

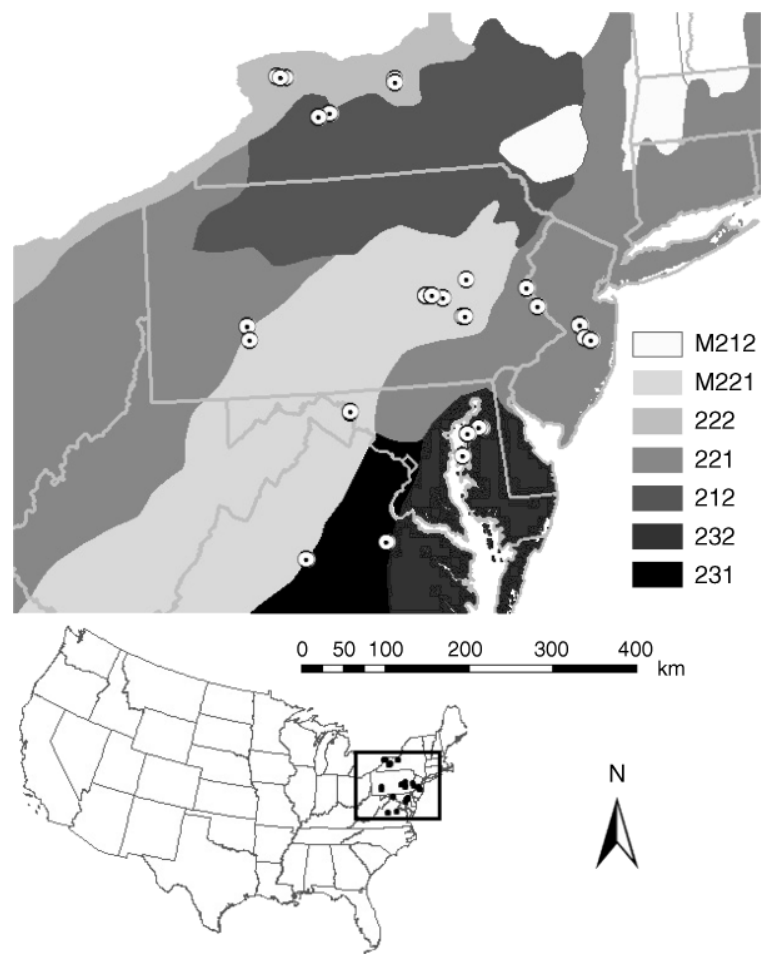

FIG. 1. Location of conservation grasslands included in the survey. Regional ecoregion provinces (Bailey 1995) include: 212 (Laurentian Mixed Forest Province), M212 (Adirondack-New England Mixed Forest-Coniferous Forest-Alpine Meadow Province), 221 (Eastern Broadleaf Forest [Oceanic] Province), 222 (Eastern Broadleaf Forest (Continental) Province), M221 (Central Appalachian Broadleaf Forest-Coniferous ForestMeadow Province), 231 (Southeastern Mixed Forest Province), and 232 (Outer Coastal Plain Mixed Forest Province). See $\langle$ http://www.fs.fed.us/colorimagemap/ecoreg1_provinces.html $\rangle$ for complete ecoregion descriptions.

The biomass samples were analyzed for cellulose, hemicellulose, and lignin. Samples were scanned on a near-infrared reflectance spectrophotometer (NIRS, Model 6500; FOSS NIRSystems, Silver Spring, Maryland, USA). A calibration set of 66 samples for neutral detergent fiber (NDF), acid detergent fiber (ADF), and acid detergent lignin (ADL) were chosen by cluster analysis of the reflectance data (Shenk and Westerhaus 1991). Calibration samples were analyzed in duplicate for NDF and ADF with the ANKOM Fiber Analyzer (ANKOM Technology Corporation, Fairport, New York, USA) following Vogel et al. (1999) and the ANKOM ADL procedure (procedure available online). ${ }^{6}$ Laboratory means were used to develop calibration equations by partial least squares regression (Shenk and Westerhaus 1991). Cellulose concentration was estimated as ADF minus ADL and hemicellulose as the difference between NDF and ADF values.

${ }^{6}\langle$ http://www.ankom.com/09_procedures/ADL\%20in\% 20beakers.pdf $\rangle$ 


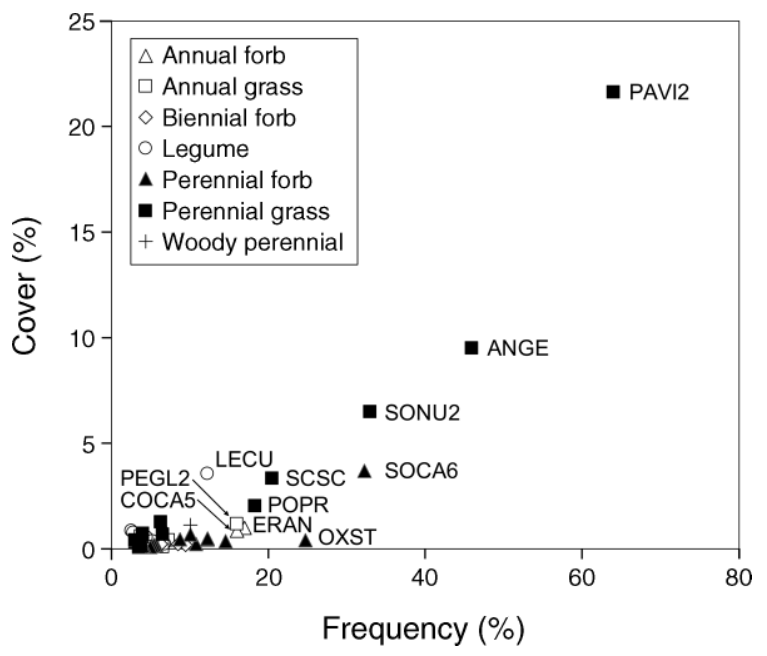

FIG. 2. Cover of the dominant species found on the conservation grasslands surveyed in the northeastern United States using the modified Whittaker plot technique. Of the 285 plant species identified across all sites, the 60 with the highest importance value are plotted in the graph, accounting for over $90 \%$ of the plant cover. The most dominant species labeled in the graph accounted for more than $70 \%$ of the plant cover, and almost $90 \%$ of that cover was from native plants. Cover values indicate the percentage of the total mean cover at all sites and in the $101-\mathrm{m}^{2}$ quadrats at each site. Frequency indicates the percentage of $1-\mathrm{m}^{2}$ quadrats in which the species were found. Species identifications are: PAVI2 (Panicum virgatum L.), ANGE (Andropogon gerardii Vitman), SONU2 (Sorghastrum nutans (L.) Nash), SOCA6 (Solidago canadensis L.), OXST (Oxalis stricta L.), SCSC (Schizachyrium scoparium (Michx.) Nash), POPR (Poa pratensis L.), ERAN (Erigeron annuus (L.) Pers.), PEGL2 (Pennisetum glaucum (L.) R. Br.), COCA5 (Conyza canadensis (L.) Cronq.), and LECU (Lespedeza cuneata (Dum.-Cours.) G. Don).

We used two methods to estimate the bioconversion potential of the biomass materials. The first, a potential ethanol yield, was calculated as $75 \%$ of the sum of cellulose and hemicellulose using the "theoretical ethanol yield calculator" (available online), ${ }^{7}$ a reasonable estimate of current commercial technology based on Dien et al. (2006). This calculation is based on the proportion of hexose and pentose sugars in the biomass and assumes that pretreatments and acid or chemical hydrolysis will make these sugars freely available for fermentation and that improved yeast strains will completely ferment both the hexoses and pentose monomers. The second method, in vitro gas production, relies on anaerobic fermentation of the biomass by a mixed microbial inoculum from the bovine rumen without pretreatment of the biomass beyond simple grinding and without addition of exogenous enzymes. This method provides an indication of fermentability that might be expected from consolidated bioprocessing, an alternative cellulosic ethanol platform that uses

7 http://www.eere.energy.gov/biomass/ethanol_yield_ calculator.html $\rangle$ anaerobic bacteria that produce their own celluloseand hemicellulose hydrolases and that ferment the resulting sugars to ethanol and other products (Lynd et al. 2002). The in vitro gas production method provides a surrogate measure of the fermentability of cellulosic biomass to ethanol, suitable for screening large numbers of biomass samples (Weimer et al. 2005). In vitro gas production analyses were conducted as described previously (Weimer et al. 2005) on composite samples for each site, and gas production data across duplicate 96-h runs were normalized using data from the fermentation of alfalfa fiber standards included in each run.

We calculated Pearson correlation coefficients $(r)$ between species richness or tall $\mathrm{C}_{4}$ prairie grass cover and chemical composition or potential ethanol yield with the PROC CORR procedure in SAS (SAS Institute 2002).

\section{RESUlts}

The tall $\mathrm{C}_{4}$ prairie grasses (Panicum virgatum $\mathrm{L}$, Andropogon gerardii Vitman, and Sorghastrum nutans (L.) Nash) were the most dominant species (Fig. 2) and the number of plant species decreased as the cover of these $\mathrm{C}_{4}$ grasses increased (Fig. $3 ; r=-0.40, P=0.0105$ ). Native species accounted for most of the 285 plant species we identified across all the conservation grasslands.

The concentration of lignin, cellulose, and hemicellulose varied with plant species composition and species richness, which ultimately affected the potential ethanol yield of the sites. Lignin concentration did not change as plant species richness increased (Fig. 4a; $P=0.9936$ ).

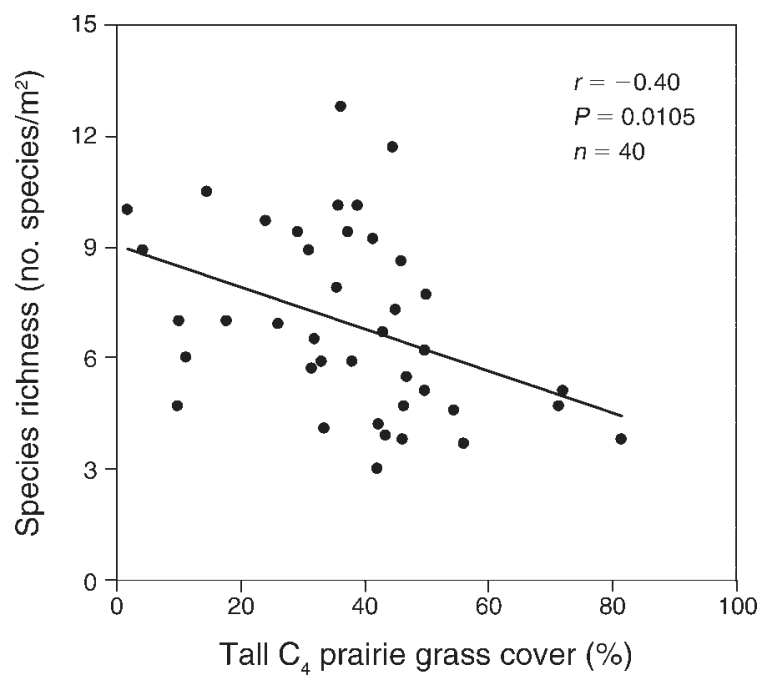

FIG. 3. Correlation of species richness with tall $\mathrm{C}_{4}$ prairie grass species cover in $1-\mathrm{m}^{2}$ quadrats. Tall $\mathrm{C}_{4}$ prairie grass species included in cover measurement were Panicum virgatum, Andropogon gerardii, and Sorghastrum nutans. The number of observations $(n=40)$ for species richness and tall $\mathrm{C}_{4}$ prairie grass cover were means of $101-\mathrm{m}^{2}$ sampling points. 

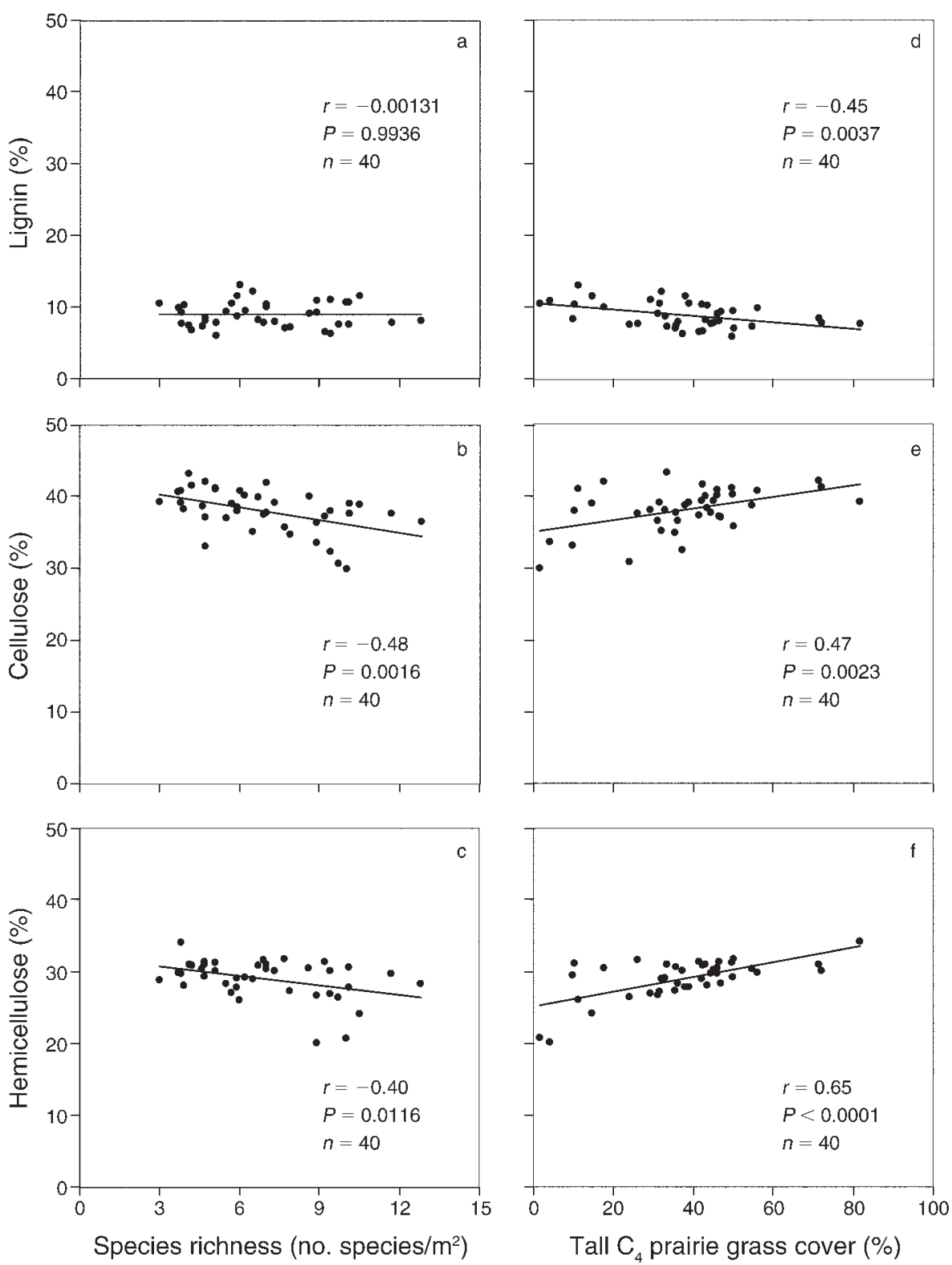

FIG. 4. Correlation of lignin, cellulose, and hemicellulose concentrations with species richness and tall $\mathrm{C}_{4}$ prairie grass species cover in $1-\mathrm{m}^{2}$ quadrats. Tall $\mathrm{C}_{4}$ prairie grass species included in cover measurement were Panicum virgatum, Andropogon gerardii, and Sorghastrum nutans. The number of observations $(n=40)$ for chemical composition, species richness, and tall $\mathrm{C}_{4}$ prairie grass cover were means of $101-\mathrm{m}^{2}$ sampling points.

However, both cellulose (Fig. 4b; $r=-0.48, P=0.0016$ ) and hemicellulose (Fig. 4c; $r=-0.40, P=0.0116$ ) were negatively correlated with plant species richness. The decrease in cellulose and hemicellulose concentration with greater species richness reduced the potential ethanol yield (on a unit biomass basis; Fig. 5a; $r=$ $-0.51, P=0.0007)$. Because aboveground biomass yield decreased with greater species richness (P. R. Adler, M. A. Sanderson, and S. C. Goslee, unpublished manuscript) potential ethanol yield on a unit land area basis was also negatively correlated with plant species richness (Fig. 5b; $r=-0.53, P=0.0005$ ). Lignin concentration was negatively correlated with the cover of tall $\mathrm{C}_{4}$ prairie grasses (Fig. $4 \mathrm{~d} ; r=-0.45, P=0.0037$ ). Both cellulose (Fig. 4e; $r=0.47, P=0.0023$ ) and hemicellulose (Fig. 4f; $r=0.65, P<0.0001$ ) concentrations were positively correlated with tall $\mathrm{C}_{4}$ prairie grass cover. The increase in cellulose and hemicellulose concentrations with tall $\mathrm{C}_{4}$ prairie grass cover resulted in an increased potential ethanol yield on a mass basis (Fig. 5c; $r=0.65, P<0.0001$ ). Because aboveground biomass yield increased with the cover of tall $\mathrm{C}_{4}$ prairie grasses (P. R. Adler, M. A. Sanderson, and S. C. Goslee, unpublished manuscript) potential ethanol yield on a unit 

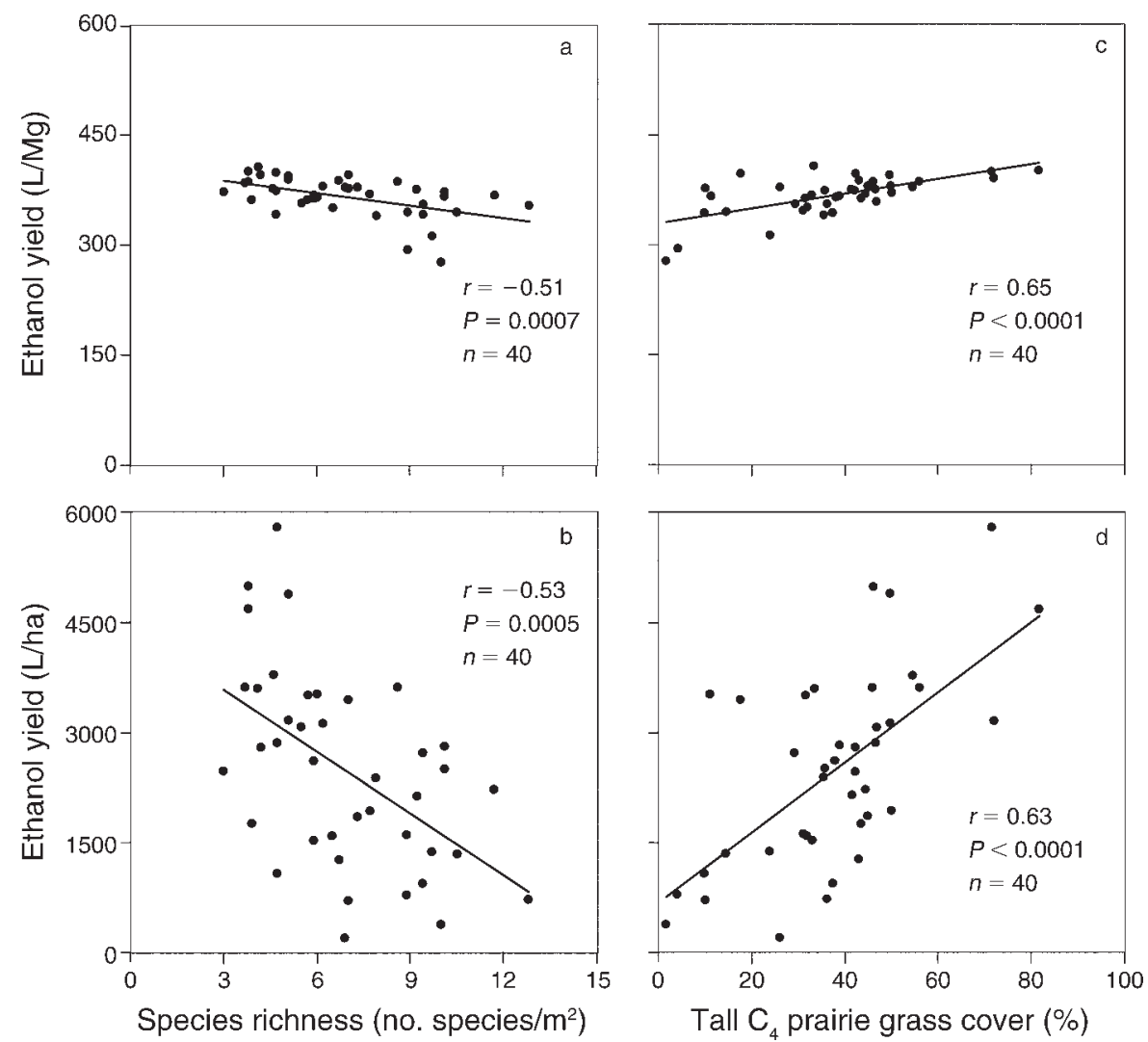

FIG. 5. Correlation of ethanol yields with species richness and tall $\mathrm{C}_{4}$ prairie grass species cover in $1-\mathrm{m}^{2}$ quadrats expressed on a unit-biomass and land-area basis. Tall $\mathrm{C}_{4}$ prairie grass species included in cover measurement were Panicum virgatum, Andropogon gerardii, and Sorghastrum nutans. The number of observations $(n=40)$ for potential ethanol yield, species richness, and tall $\mathrm{C}_{4}$ prairie grass cover were means of $101-\mathrm{m}^{2}$ sampling points.

land area basis was also positively correlated with tall $\mathrm{C}_{4}$ prairie grass cover (Fig. 5d; $r=0.63, P<0.0001$ ).

Potential ethanol yield estimated by the in vitro gas production and chemical composition methods reflect different conversion processes. The in vitro gas production method includes the potential inhibitory effects from lignin, which may not be present in appropriately pretreated biomass. By contrast, ethanol yields estimated by chemical composition assume there are no inhibitory effects of either residual lignin or of sideproducts of pretreatment. Therefore it is not surprising that results comparing the two methods are not completely consistent. The in vitro gas production method was not related to species richness (Fig. 6a; $r$ $=0.11, P>0.5)$; however, as with ethanol yield predicted from chemical composition, gas production was positively correlated with tall $\mathrm{C}_{4}$ prairie grass cover (Fig. 6b; $r=0.37, P=0.0192$ ).

\section{Discussion}

Plant species composition affected the concentration of lignin, cellulose, and hemicellulose in the biomass (Fig. 4) and significantly altered the potential ethanol yield on these conservation grasslands. From linear regression analysis of data in Fig. 5, the potential ethanol yield decreased $14 \%$ per unit biomass and $77 \%$ per unit land area as plant species richness increased from 3 to 12.8 species per $\mathrm{m}^{2}$. The reduction in potential ethanol yield was magnified because aboveground biomass yield per unit area also decreased with greater plant species richness, leading to a decrease in potential ethanol yield per unit land area. Potential ethanol yield, however, increased $24 \%$ per unit biomass and more than $500 \%$ per unit land area as the cover of tall $\mathrm{C}_{4}$ prairie grasses increased from $1.7 \%$ to $81.6 \%$. Results from the alternative method of assessing biomass fermentability, in vitro fermentation, did not indicate a response to species richness, but did reveal a positive relationship between fermentability and cover of tall $\mathrm{C}_{4}$ prairie grasses. The effect of plant species composition on potential ethanol yield needs to be considered when describing ethanol production from diverse grasslands.

Research on the chemical composition of biomass has focused on individual forage and crop species such as switchgrass, reed canarygrass, alfalfa, and maize (Dien et al. 2006) with little work on mixed-species biomass (Tracy and Faulkner 2006). Detailed analyses of cell wall composition and ethanol yields of switchgrass, reed 
canarygrass, and alfalfa revealed significant species differences (Dien et al. 2006). Lignin, cellulose, and hemicellulose compositions were within $5 \%$ between reed canarygrass and switchgrass harvested at maturity. However, lignin and cellulose were higher and hemicellulose lower in alfalfa stems compared with reed canarygrass and switchgrass. In our study, many nonagricultural plants contributed significantly to the biomass on the sites with greater plant species richness. Most of the nonagricultural species were forbs and might be expected to have very different biomass composition compared with the $\mathrm{C}_{4}$ grasses and could reduce the ethanol production potential. We need to know more about the chemical composition of these species particularly in the light of interest in low-input high diversity (LIHD) grasslands for biomass production (Tilman et al. 2006).

Plant developmental morphology also affects plant cell wall composition and consequently potential ethanol yields (Sanderson and Wolf 1995, Casler and Boe 2003, Dien et al. 2006). Therefore, time of biomass harvest will also affect potential ethanol yields. Lignin, cellulose, and hemicellulose concentrations in $\mathrm{C}_{4}$ grasses generally increase with plant maturity (Sanderson and Wolf 1995). Concentrations of cell wall components also increase across seasonal harvest times from summer to fall (Casler and Boe 2003, Dien et al. 2006) and spring after over wintering in the field (Adler et al. 2006). The $\mathrm{C}_{4}$ grasses were mature (past seed set) by the time they were harvested in our study and the lignin, cellulose, and hemicellulose concentrations would be expected to be in between that expected for a late summer or fall harvest.

Competitively dominant species such as the tall $\mathrm{C}_{4}$ prairie grasses are critical to the function of biomass production in native (Smith and Knapp 2003) and restored conservation grasslands (Baer et al. 2002) often accounting for $>70 \%$ of the biomass. Croplands restored to prairie typically have fewer plant species than undisturbed prairies (Baer et al. 2004), a challenge to be faced with establishing highly diverse prairie ecosystems whether for conservation grasslands such as CRP or a future biofuel feedstock. In native prairies, the tall $\mathrm{C}_{4}$ prairie grasses such as big bluestem and switchgrass, dominate different landscape positions, with switchgrass being a more mesic grass (Knapp 1985 ) and consequently, planting mixtures of tall $\mathrm{C}_{4}$ prairie grasses may be beneficial to exploit these differences among species in site adaptability.

A number of factors could lead to the large range of native $\mathrm{C}_{4}$ grass cover observed on these conservation grasslands. During the establishment of the $\mathrm{C}_{4}$ grasses lack of a firm seed bed, planting seed too deeply, lack of rainfall during establishment, and plant competition from the seed bank or surviving perennial species associated with previous land history can all influence community assembly. According to records provided by the land managers, fewer than 10 species were planted at each site; however, we identified many species from
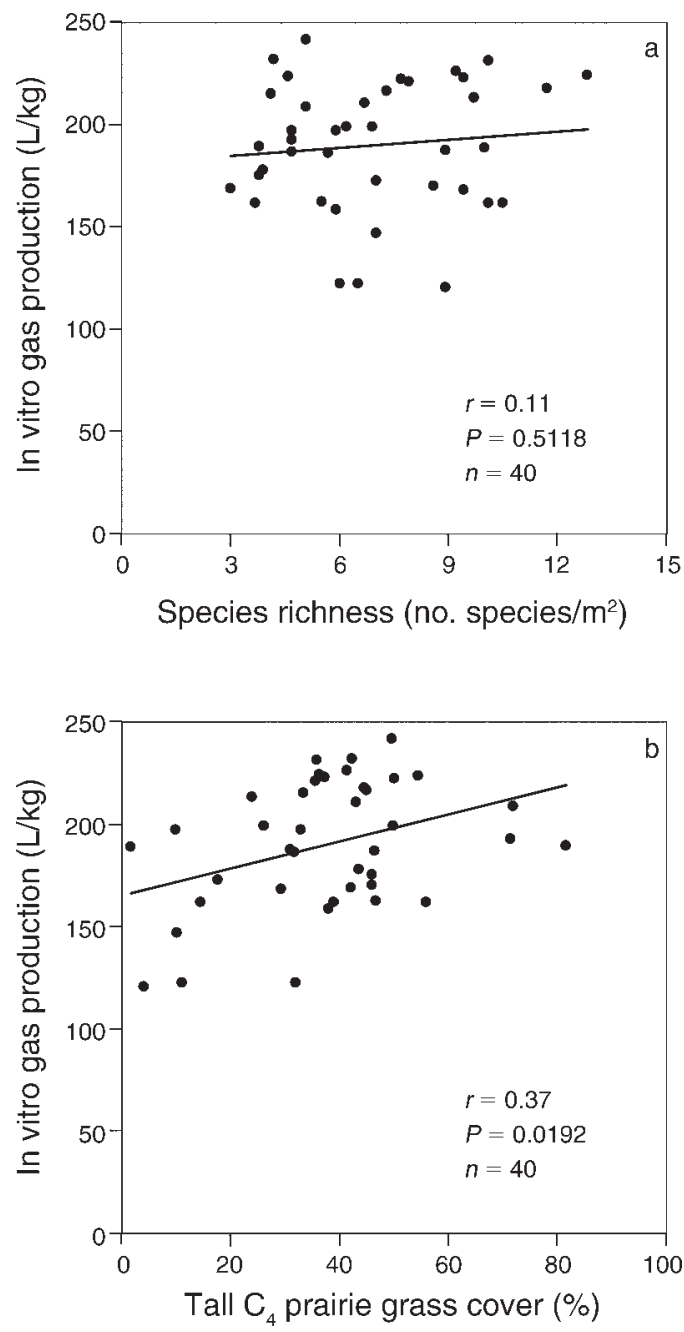

FIG. 6. Correlation of in vitro gas yields with species richness and tall $\mathrm{C}_{4}$ prairie grass species cover in $1-\mathrm{m}^{2}$ quadrats expressed on a unit biomass basis. Tall $\mathrm{C}_{4}$ prairie grass species included in cover measurement were Panicum virgatum, Andropogon gerardii, and Sorghastrum nutans. The number of observations $(n=40)$ for in vitro gas yields, species richness, and tall $\mathrm{C}_{4}$ prairie grass cover were means of $101-\mathrm{m}^{2}$ sampling points.

several functional groups (Fig. 2). The total plant species richness of the sites ranged from 12 to 60 species with a mean of 34 per 0.1 ha. The majority of these plant species were native and accounted for almost $80 \%$ of the plant cover. The most dominant plant species are specifically identified in Fig. 2; they accounted for more than $70 \%$ of the plant cover and almost $90 \%$ of that cover was from native plants. The three most dominant plant species were the tall native $\mathrm{C}_{4}$ prairie grasses. The highly competitive native $\mathrm{C}_{4}$ grasses (Fargione and Tilman 2005) reduced the number of plant species on the conservation grasslands (Fig. 3). The characteristic of having a higher use efficiency of nutrients would allow native $\mathrm{C}_{4}$ grasses to be able to produce more biomass with the limited resources available at these sites. 


\section{Implications of managing conservation grasslands for biofuel production}

The potential ethanol yield ranged from 200 to almost $5800 \mathrm{~L} /$ ha in this survey of 34 conservation grasslands in the northeastern United States. Conservation grasslands dominated by tall native $\mathrm{C}_{4}$ prairie grasses had more aboveground biomass, fewer plant species, higher ethanol yield per unit biomass, and consequently a higher ethanol yield per unit land area than other sites. Management to increase the cover of tall $\mathrm{C}_{4}$ prairie grasses on low productivity sites may be necessary to increase biomass and biofuel yields. Although 285 plant species were identified on the grasslands in this survey, native species were dominant. Tall native $\mathrm{C}_{4}$ prairie grasses are highly competitive and efficient users of limited resources, allowing them to produce more biomass than other species. $\mathrm{C}_{4}$ grasses and legumes have been shown to be key functional groups for biomass productivity (Fornara and Tilman 2008), producing equivalent biomass yields compared to sites with higher numbers of species. Consequently, management to enhance legume abundance and $\mathrm{N}_{2}$ fixation may be critical to yield with reduced inputs. Our data suggest that the species composition of plant mixtures used for low-input high-diversity systems (Tilman et al. 2006) affects both biomass production and chemical composition. Including a large proportion of species with undesirable fermentation characteristics could reduce ethanol yields.

\section{ACKNOWLEDGMENTS}

The authors thank Matthew Myers, Jeff Gonet, John Everhart, Dennis Genito, Kim Darling, Stephen LaMar, and Steven Masterson for their excellent technical assistance, and USDA-NRCS personnel and landowners for access to sites. Mention of trade names or commercial products in this publication is solely for the purpose of providing specific information and does not imply recommendation or endorsement by the U.S. Department of Agriculture.

\section{Literature Cited}

Adler, P. R., M. A. Sanderson, A. A. Boateng, P. J. Weimer, and H. G. Jung. 2006. Biomass yield and biofuel quality of switchgrass harvested in fall or spring. Agronomy Journal 98: $1518-1525$.

Baer, S. G., J. M. Blair, S. L. Collins, and A. K. Knapp. 2004. Plant community responses to resource availability and heterogeneity during restoration. Oecologia 139:617-639.

Baer, S. G., D. J. Kitchen, J. M. Blair, and C. W. Rice. 2002. Changes in ecosystem structure and function along a chronosequence of grasslands restored through the Conservation Reserve Program. Ecological Applications 12:16881701.

Bailey, R. G. 1995. Description of the ecoregions of the United States. Second edition. USDA-Forest Service Miscellaneous Publication 1391. USDA-Forest Service, Washington, D.C., USA. 〈http://www.fs.fed.us/colorimagemap/ecoreg 1_ provinces.html $\rangle$

Casler, M. D., and A. R. Boe. 2003. Cultivar $\times$ environment interactions in switchgrass. Crop Science 43:2226-2233.

Collins, S. L., A. K. Knapp, J. M. Briggs, J. M. Blair, and E. M. Steinauer. 1998. Modulation of diversity by grazing and mowing in native tallgrass prairie. Science 280:745-747.
De La Torre Ugarte, D. G., M. Walsh, H. Shapouri, and S. P. Slinsky. 2003. The economic impacts of bioenergy crop production on U.S. agriculture. Agricultural Economics Report No. 816. USDA Office of Energy Policy and New Uses, Washington, D.C., USA.

Dien, B. S., H. G. Jung, K. P. Vogel, M. D. Casler, J. F. S. Lamb, L. Iten, R. B. Mitchell, and G. Sarath. 2006. Chemical composition and response to dilute-acid pretreatment and enzymatic saccharification of alfalfa, reed canarygrass, and switchgrass. Biomass Bioenergy 30:880-891.

Fales, S. L., and J. O Fritz. 2007. Factors affecting forage quality. Pages 569-580 in R. F. Barnes, C. J. Nelson, K. J. Moore, and M. Collins, editors. Forages, volume II: the science of grassland agriculture. Sixth edition. Blackwell Publishing, Ames, Iowa, USA.

Fargione, J., and D. Tilman. 2005. Niche differences in phenology and rooting depth promote coexistence with a dominant $\mathrm{C}_{4}$ bunchgrass. Oecologia 143:598-606.

Fornara, D. A., and D. Tilman. 2008. Plant functional composition influences rates of soil carbon and nitrogen accumulation. Journal of Ecology 96:314-322.

Fukami, T., and P. J. Morin. 2003. Productivity-biodiversity relationships depend on the history of community assembly. Nature 424:423-426.

Gough, L., C. W. Osenberg, K. L. Gross, and S. L. Collins. 2000. Fertilization effects on species density and primary productivity in herbaceous plant communities. Oikos 89: $428-439$.

Knapp, A. K. 1985. Effect of fire and drought on the ecophysiology of Andropogon gerardii and Panicum virgatum in a tallgrass prairie. Ecology 66:1309-1320.

Lant, C. L., S. E. Kraft, J. Beaulieu, D. Bennett, T. Loftus, and J. Nicklow. 2005. Using GIS-based ecological-economic modeling to evaluate policies affecting agricultural watersheds. Ecological Economics 55:467-484.

Lynd, L. R., P. J. Weimer, W. H. van Zyl, and I. S. Pretorius. 2002. Microbial cellulose utilization: fundamentals and biotechnology. Microbiology and Molecular Biology Review 66:506-577.

McLauchlan, K. K., S. E. Hobbie, and W. M. Post. 2006. Conversion from agriculture to grassland builds soil organic matter on decadal timescales. Ecological Applications 16: 143-153.

Michalet, R., R. W. Brooker, L. A. Cavieres, Z. Kikvidze, C. J. Lortie, F. I. Pugnaire, A. Valiente-Banuet, and R. M. Callaway. 2006. Do biotic interactions shape both sides of the humped-back model of species richness in plant communities? Ecology Letters 9:767-773.

Murray, L. D., L. B. Best, T. J. Jacobsen, and M. L. Braster. 2003. Potential effects on grassland birds of converting marginal cropland to switchgrass biomass production. Biomass Bioenergy 25:167-175.

National Research Council. 2000. Biobased industrial products: priorities for research and commercialization. National Academy Press, Washington, D.C., USA.

Partel, M., L. Laanisto, and M. Zobel. 2007. Contrasting plant productivity-diversity relationships across latitude: the role of evolutionary history. Ecology 88:1091-1097.

Sanderson, M. A., G. E. Brink, K. F. Higgins, and D. E. Naugle. 2004. Alternative uses of warm-season forage grasses. Pages 389-417 in L. E. Moser, et al. editors. Warm-season $\left(\mathrm{C}_{4}\right)$ grasses. Agronomy monograph no. 45. American Society of Agronomy, Madison, Wisconsin, USA.

Sanderson, M. A., and D. D. Wolf. 1995. Switchgrass biomass composition during morphological development in diverse environments. Crop Science 35:1432-1438.

SAS Institute. 2002. SAS/STAT user's guide, Version 9.1. SAS Institute, Cary, North Carolina, USA.

Shenk, J. S., and M. O. Westerhaus. 1991. Population definition, sample selection, and calibration procedures for 
near infrared reflectance spectroscopy. Crop Science 31:469474.

Smith, M. D., and A. K. Knapp. 2003. Dominant species maintain ecosystem function with non-random species loss. Ecology Letters 6:509-517.

Stohlgren, T. J., K. A. Bull, Y. Otsuki, C. A. Villa, and M. Lee. 1998. Riparian zones as havens for exotic plant species in the central grasslands. Plant Ecology 138:113-125.

Stohlgren, T. J., M. B. Falkner, and L. D. Schell. 1995. A modified-Whittaker nested vegetation sampling method. Vegetatio 117:113-121.

Tilman, D., J. Hill, and C. Lehman. 2006. Carbon-negative biofuels from low-input high-diversity grassland biomass. Science 314:1598-1600.

Tracy, B. F., and D. B. Faulkner. 2006. Pasture and cattle responses in rotationally stocked grazing systems sown with differing levels of species richness. Crop Science 46:20622068.

Veech, J. A. 2006. A comparison of landscapes occupied by increasing and decreasing populations of grassland birds. Conservation Biology 20:1422-1432.

Vogel, K. P., J. F. Pedersen, S. D. Masterson, and J. J. Toy. 1999. Evaluation of a filter bag system for NDF, ADF, and IVDMD forage analysis. Crop Science 39:276-279.

Weimer, P. J., B. S. Dien, T. L. Springer, and K. P. Vogel. 2005. In vitro gas production as a surrogate measure of the fermentability of cellulosic biomass to ethanol. Applied Microbiology and Biotechnology 67:52-58.

Zheng, F. L., S. D. Merrill, C. H. Huang, D. L. Tanaka, F. Darboux, M. A. Liebig, and A. D. Halvorson. 2004. Runoff, soil erosion, and erodibility of conservation reserve program land under crop and hay production. Soil Science Society of America Journal 68:1332-1341. 